\title{
TRANSPIRATION CAPABILITY OF SEVERAL LOWLAND FOREST TREE SPECIES
}

\author{
IRSAN, M.F. ${ }^{1}$, SULISTYAWATI, E. ${ }^{1 *}$, HADIYANE, A. ${ }^{1}$ and HIDAYATI, N. ${ }^{2}$ \\ ${ }^{1}$ Forestry Engineering Program, School of Life Sciences and Technology, Institut Teknologi Bandung, \\ Bandung, Indonesia, Jalan Ganesha No. 10 Bandung 40132 \\ ${ }^{2}$ Research Center for Biology, Indonesian Institute of Science, \\ Jalan Raya Jakarta-Bogor Km 46 Cibinong 16911 \\ *E-mail: endah@sith.itb.ac.id
}

Accepted 6 May 2020, Published online 6 July 2020

\begin{abstract}
Plant transpiration is the key to restore the water balance of mining site. Plant transpiration will relate to water loss rate from the land, therefore the transpiration ability of plants can be used as one criterion on the selection of tree species for postmining land reclamation program. This research aimed to compare transpiration capability among selected tree species and to compare potential loss of water through transpiration and the rate of water input through rainfall. Seven native lowland rainforest species commonly found in the Bangka Belitung Islands were used in this research. We measured parameters affecting transpiration rates, i.e. stomatal conductance, leaf area index (LAI), and subsequently calculated canopy conductance and transpiration rates. The calculated transpiration rate of each species was Shorea leprosula (4.47 mm/day), Hopea odorata $(3.93 \mathrm{~mm} /$ day), Aquilaria malaccensis $(3.34 \mathrm{~mm} /$ day $)$, Shorea javanica $(2.59 \mathrm{~mm} /$ day), Terminalia catappa $(2.01 \mathrm{~mm} /$ day $)$, Flacourtia rukam $(1.96 \mathrm{~mm} /$ day), and Eusideroxylon zwageri $(1.35 \mathrm{~mm} /$ day). During the driest month, Shorea leprosula would have the highest potential of water loss through transpiration than that in other studied species.
\end{abstract}

Key words: Post-mining site, stomatal conductance, transpiration, Bangka Belitung native species

\section{INTRODUCTION}

Exploitation of Indonesian natural resources by mining operations has led to enormous negative environmental impacts (Pongtuluran, 2015). Mining activities have transformed the landscape and degraded the quality of the environment. One form of post-mining environmental damage rehabilitation is reclamation. Under Indonesian regulation, every mining activity is required to carry out reclamation (ESDM, 2014). Today, there are still many problems in implementing land reclamation including the problem of water balance. The loss of vegetation on mining lands could lead to the problem of water balance (Patiung et al., 2011). The problem of water balance can be serious because there is no guarantee that the availability of water in mining areas has reached a safe stage. Therefore, it important that tree species to be planted during land reclamation will not create water balance problem. Currently, the selection of species for post-mining reclamation

* To whom correspondence should be addressed. generally does not take into account parameters related to water balance. Therefore, this research intends to show a parameter related to water balance that can be used as a criterion for species selection, i.e. the capability of local tree species in conducting transpiration.

Forest transpiration relies on the average response of each species (Granier et al., 1995). Transpiration capabilities can vary among trees. Transpiration capability of trees determines how much water is returned to the air and thus also determining the balance of water on the surface. Water balance can be simply expressed in the following formula (Asdak, 2014).

$$
P=E_{t}+\Delta S+R
$$

With $\mathrm{P}(\mathrm{tmm})^{-1}$ as precipitation or rainfall and Et $\left(\mathrm{mm} \mathrm{t}^{-1}\right)$ is evapotranspiration rate. In this study, the formula is simplified by not considering the value of storage (S) and runoff (R), and evapotranspiration is limited only to the process of transpiration. This water balance formula is used to 
simply compare the rate of water input through precipitation and water returning to the air by transpiration of a forest stand.

The transpiration rate can be calculated using the following formula (Landsberg \& Sands, 2011):

$$
E t=\frac{s \varphi_{n a}+g_{b} \rho_{a} c_{p a} \mathrm{D}}{\left(s+\gamma\left(1+\frac{g b}{g c}\right)\right.} / \lambda
$$

This equation model consists of a number of parameters affecting transpiration. As $\varphi_{n a}\left(\mathrm{Wm}^{-2}\right)$ is sunlight absorbed by the canopy, $g b\left(\mathrm{~ms}^{-1}\right)$ is the boundary layer conductance that is the effectiveness of leaf to transfer an entity from outside to inside the leaf, which can be estimated from the dimensional characteristic of the leaf and wind speed around the leaf (Landsberg \& Sands, 2011). $\mathrm{D}(\mathrm{Pa})$ is atmospheric vapour pressure deficit, which is a change in vapour pressure of the air that is affected by the air temperature, and $g c\left(\mathrm{~ms}^{-1)}\right.$ is canopy conductance, which is the capacity of stomatal diffusion that is forwarded to all the leaves on the level of the canopy. Canopy conductance can be calculated based on two main parameters: stomatal conductance $\left(\mathrm{g}_{\mathrm{s}}\right)$ and Leaf Area Index (LAI). Constants used in the transpiration rate equation are $\mathrm{S}\left(\mathrm{PAK}^{-1}\right)$, which is saturated vapor pressure, $\rho_{a}\left(\mathrm{Kg} \mathrm{m}^{-3}\right)$ which is density of dry air, $c_{p a}\left(\mathrm{~J} \mathrm{~kg}^{-1} \mathrm{~K}^{-1)}\right.$ which is specific heat of dry air, and $\gamma(\mathrm{Pa} \mathrm{K}-1)$ which is psychrometric constant.

The objectives of this research were (1) to compare transpiration capability among selected trees of lowland forest, (2) to compare potential loss of water through transpiration and the rate of water input through rainfall on the study site in Bangka Belitung islands.

\section{MATERIALS AND METHODS}

\section{Materials}

The study used seven native species commonly found in the lowland rainforests of Sumatra Island as well as Bangka Belitung Islands. The seven species are Hopea odorata Roxb., Shorea leprosula Mig., Shorea javanica Koord. and Valeton, Flacourtia rukam Zoll. and Moritzi, Aquilaria malaccensis Benth, Eusideroxylon zwageri Teijsm. and Binn., and Terminalia catappa L. The measurement of stomatal conductance was carried out to sampled trees located at EcoPark, LIPI, Cibinong. Two to three individuals per species was selected for stomatal conductance measurement. The measurements were conducted in two leaves for each individual with eight repeated measurements on the same leaf. Measurement for LAI calculation was conducted to fully-grown trees in Bogor Botanic
Garden; all sampled individuals had diameters between 50 to $100 \mathrm{~cm}$. The rainfall data referring to Bangka Belitung region at year 2013 was taken from the statistic of Indonesian Agency for Meteorological, Climatological and Geophysics (BMKG) (Statistik, 2016).

\section{Procedures \\ Measurement of stomatal conductance (gs)}

Stomatal conductance was measured using IRGA (Infrared Gas Analyzer) by pinching the leaves in the apparatus's chamber. The data was recorded using LCI ADC Bioscientific Ltd. Photosynthesis System. The unit as measured by IRGA is molm ${ }^{-2} \mathrm{~s}^{-1}$; this unit was subsequently converted into $\mathrm{ms}^{-1}$ using the following equation (Landsberg \& Sands, 2011):

$$
g\left(m s^{-1}\right)=\left(\frac{R(T+273)}{P}\right) \times g\left(\text { molm }^{-2} S^{-1}\right)
$$

Where $\mathrm{R}=8.314 \mathrm{JK}^{-1} \mathrm{~mol}^{-1}$ is the air constant, $\mathrm{T}\left({ }^{\circ} \mathrm{C}\right)$ is the air temperature and $\mathrm{P}(\mathrm{Pa})$ is the pressure.

\section{Calculation of leaf area index (LAI)}

To calculate the Leaf Area Index Value, the equation provided below is used (Landsberg \& Sands, 2011):

$$
L=\int_{0}^{H} \frac{\sigma_{F} W_{F}}{V}(z) d z
$$

Value of $\sigma_{F}$ (specific leaf area), which is the ratio of leaf area to leaf weight ratio. $\mathrm{W}_{\mathrm{F}}(\mathrm{Kg})$ is the weight of the canopy. $\mathrm{V}$ is the volume of the canopy unit is calculated by the ellipsoid volume approach (Thorne et al., 2002).

\section{Calculation of canopy conductance}

Canopy conductance values is influenced by stomata conductance (Landsberg \& Sands, 2011), calculated with the following formula:

$$
g_{c}=\left(g_{S x} / k\right) \ln \left(\frac{\varphi_{g S}+\varphi_{0}}{\varphi_{g S}+\varphi_{0} e^{-k L}}\right)
$$

In the formula above, $g_{S x}\left(\mathrm{~ms}^{-1}\right)$ is the maximum condition of Stomatal Conductance, $\mathrm{k}$ is the light extinction coefficient with value of 0,54 , $\varphi_{g S}\left(\mathrm{Wm}^{-2}\right)$ is the sensitivity of the stomata when exposed to solar radiation, and $\mathrm{L}$ is the leaf area index (LAI).

\section{Calculation of transpiration rate}

The rate of transpiration was calculated by using empirical equation of Penman-Monteith divided by the latent heat of water vaporization 
using the following formula (Landsberg \& Sands, 2011):

$$
E=\frac{s \varphi_{n a}+g_{b} \rho_{a} c_{p a} D}{s+\gamma\left(1+\frac{g_{b}}{g_{c}}\right)} / \lambda
$$

Where $\mathrm{s}\left(\mathrm{PAK}^{-1}\right)$ is the initial saturation vapor pressure of water, $\varphi_{n a}\left(\mathrm{Wm}^{-2}\right)$ is the solar radiation absorbed by the canopy, $\mathrm{g}_{\mathrm{b}}\left(\mathrm{ms}^{-1}\right)$ is the boundary layer conductance, $\rho_{a}=1.204 \mathrm{kgm}^{-3}$ is the density of dry air, $C_{p a}=1004 \mathrm{~J} \mathrm{~kg}^{-1} \mathrm{~K}^{-1}$ is the specific heat of dry air, $\mathrm{D}(\mathrm{Pa})$ is the vapor pressure deficit of the air, $\gamma=66.1 \mathrm{PaK}^{-1}$ is the constant of psychrometric, $\mathrm{g}_{\mathrm{c}}\left(\mathrm{ms}^{-1}\right)$ is the canopy conductance and $\lambda=2.45$ MJ kg-1.

\section{RESULTS AND DISCUSSION}

\section{Stomatal conductance and LAI}

Stomata occupy a central position in the water loss from the plant and the exchange of CO2 (Jones, 1997). Figure 1 presents variation of stomatal conductance. The highest value was recorded for Terminalia catappa, meanwhile the lowest value was recorded for Eusideroxylon zwageri. Hidayati et al. (2013) suggests that external factors (light, temperature and air pressure) will affect stomatal conductance. Given the similar environmental condition among sampled trees during the measurements, therefore the variation in stomatal conductance found in this research could be due to differences in the plant's characteristics. However, the results of this research suggests that variation on stomatal conductance among the seven species was low (Figure 1). Other study conducted on similar environmental reported a wider variation of stomatal conductance, i.e. between $0.11 \mathrm{molm}^{-2} \mathrm{~s}^{-1}$ to $0.75 \mathrm{molm}^{-2} \mathrm{~s}^{-1}$ (Hidayati et al., 2013).

Measurement result showed the values of LAI among the seven tree species were between 1.2 (Flacourtia rukam) to 6.7 (Shorea leprosula) as presented in Figure 2. LAI is an important factor affecting transpiration. From their study that compared canopy conductance on different forest stands, Granier \& Breda (1997) concluded that LAI plays a more important role than species composition. Canopy conductance is a parameter that directly affects the rate of transpiration. Furthermore, modeling in the existing researchindicates that the value of transpiration based on

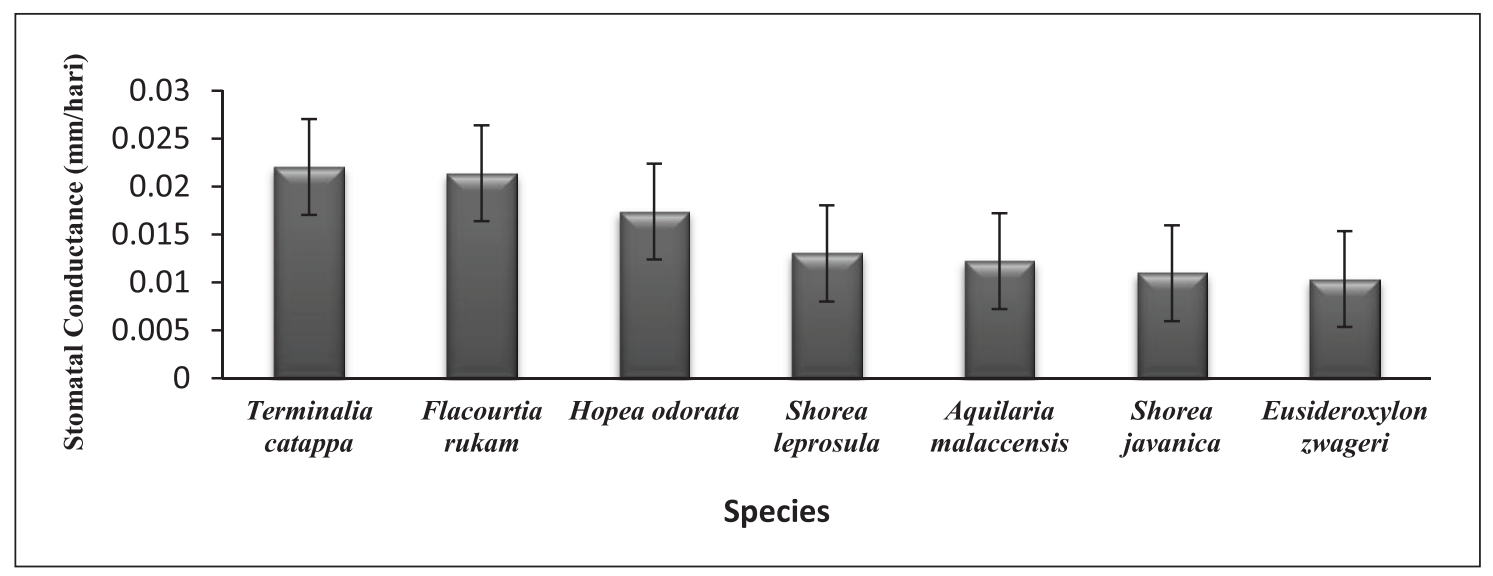

Fig. 1. Stomatal conductance of the seven lowland rainforest species.

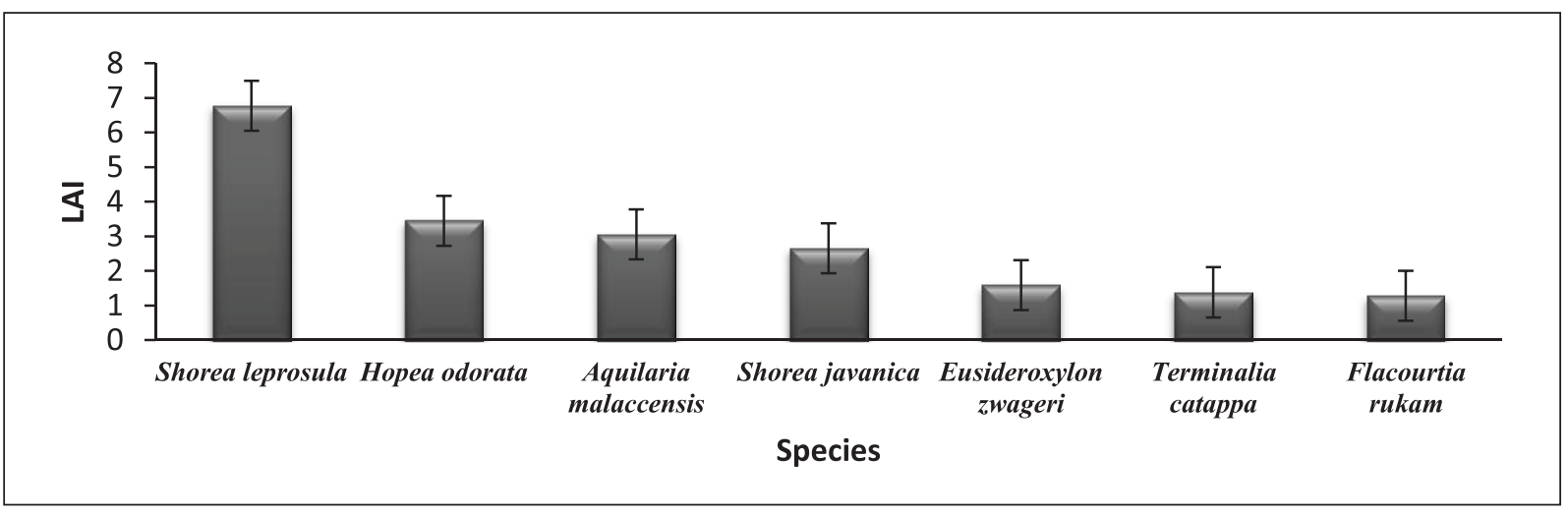

Fig. 2. Leaf area index (LAI) of seven lowland rainforest species. 


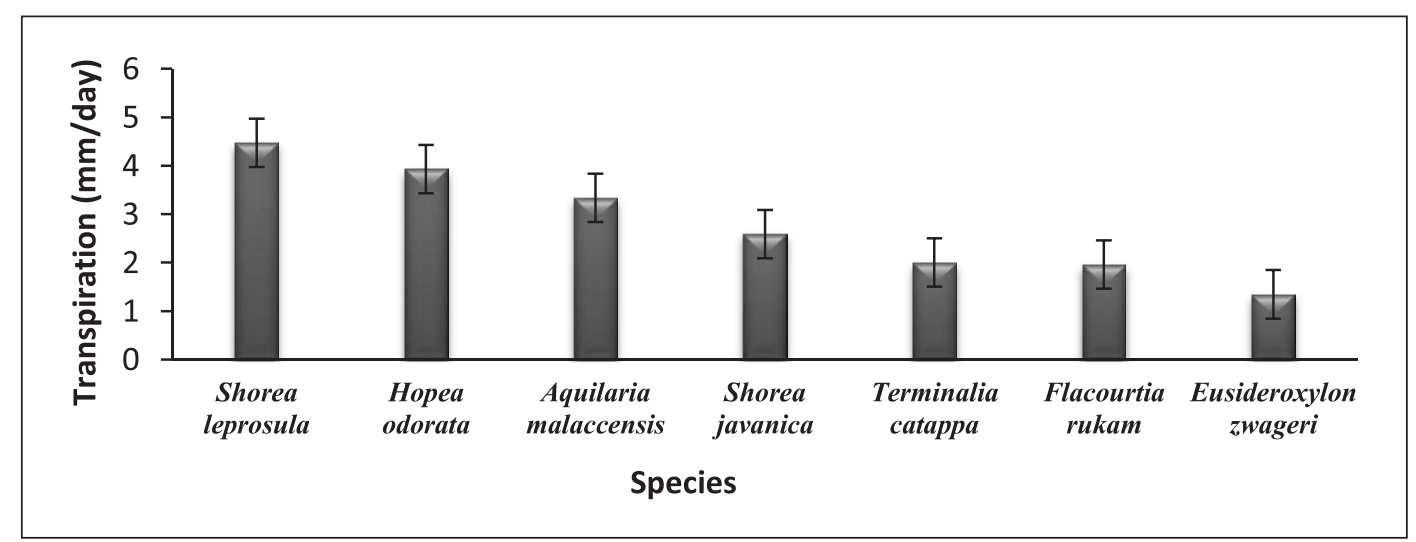

Fig. 3. Calculated transpiration of seven lowland rainforest species.

canopy conductance and transpiration value of forest stands based on the calculation of sap flow shows the strong relation between the LAI with the total transpiration of the tree (Granier \& Breda, 1997).

The calculated transpiration rates (Figure 3) showed that Shorea leprosula had the highest transpiration rate; meanwhile the lowest transpiration rate was recorded for Eusideroxylon zwagery. The transpiration rate of trees depends on the value of LAI and stomatal conductance. Both factors give an impact on the ability of plant to perform transpiration. In this research, however, the values of stomatal conductance among the species were not much different (Figure 1). Therefore, differences in the transpiration rate was likely due to the large variation on LAI (Figure 2) and this resulted in large difference on transpiration capabilities between tree species. Shorea leprosula that had the highest value of LAI showed the highest transpiration rate compared with the other six species. A further increase in LAI will give additional contribution to water loss (Ehlers \& Goss, 2002). The more extensive the canopy of the trees, the more the leaves loses water through transpiration. Soil evaporation also contributes to the transfer of water to the air. In a situation where the canopy covers the soil, the process of evaporation from the ground is inhibited, thus making the water flow into the air mostly through transpiration.

\section{Comparison of species transpiration rate with rainfall}

Based on the rainfall data for Bangka Belitung region (Statistik, 2016), the lowest rainfall was recorded on August 2013, i.e. $84.5 \mathrm{~mm} / \mathrm{month}$. In this research, the lowest rainfall in a year is considered as the most critical time as a tree having transpiration rate higher than rainfall would contribute to the net water loss from ecosystem through transpiration. This research found three species having such characteristics. Shorea leprosula, Hopea odorata, Aquilaria malaccensis had transpiration rates greater than $84.5 \mathrm{~mm} /$ month, which is $134.11 \mathrm{~mm} / \mathrm{month}, 117.85 \mathrm{~mm} / \mathrm{month}$, and $100.16 \mathrm{~mm} / \mathrm{month}$, respectively. Therefore, in the context of mined area in Bangka Belitung region, the use of those tree species for revegetation could potentially lead to the net water loss especially during the lowest rainfall month. Meanwhile, the four other species had lower transpiration rates, thus are potentially safer in terms of preventing net water loss from ecosystem.

\section{CONCLUSION}

The transpiration rates among the seven lowland rainforest tree species studied, from the highest to the lowest values, were $4.47 \mathrm{~mm} /$ day (Shorea leprosula), $3.93 \mathrm{~mm} /$ day (Hopea odorata), $3.34 \mathrm{~mm} /$ day (Aquilaria malaccensis), $2.59 \mathrm{~mm} /$ day (Shorea javanica), $2.01 \mathrm{~mm} /$ day (Terminalia catappa), 1.96 $\mathrm{mm} /$ day (Flacourtia Rukam), and $1.35 \mathrm{~mm}$ /day (Eusideroxylon zwageri). If being used for reclamation on mined area in Bangka Belitung region, Shorea leprosula would have the highest potential of water loss through the transpiration than other studied species during the driest month. The water use of Eusideroxylon zwageri was the least among other studied species.

\section{ACKNOWLEDGEMENT}

The author would like to thank the Biology Research Center of LIPI and Bogor Botanical Gardens for the facilities, permit, and cooperation. 


\section{REFERENCES}

Asdak, C. 2014. Hidrologi dan Pengelolaan Air Sungai. Yogyakarta: Gadjah Mada University Press.

Badan Pusat Statistik, 2016. Badan Pusat Statistik Provinsi Kepulauan Bangka Belitung (Statistics of Kepulauan Bangka Belitung). http://babel. bps.go.id. [Accessed 17 Mei 2016].

Ehlers, W. \& Goss, M. 2002. Water Dynamics in Plant Production. UK: Cabl Publishing.

Granier, A. \& Breda, N. 1996. Modelling canopy conductance and stand transpiration of an oak forest from sap flow measurements. Annals of Forest Science, 53: 537-546.

Granier, A., Huc, R. \& Barigah, S.T. 1995. Transpiration of natural rain forest and its dependence on climatic factor. Agricultural and Forest Meteorology, Volume 78, pp.

Hidayati, N., Mansur, M. \& Juhaeti, T. 2013. Variation in carbondioxide (CO2) absorption of tree species in "Ecopark" Cibinong in relation to green house gas mitigation. Buletin Kebun Raya, Volume 16, pp. 38-50.
Jones, H.G. 1997. Stomatal control of photosynthesis and transpiration. Journal of Experimental Botany, Volume 49, pp. 287-298.

Landsberg, J. \& Sands, P. 2011. Physiological Ecology of Forest Production: Principles, Processes, and Models., USA: Academic Press.

Patiung, O., Sinukaban, N., Tarigan, S.D. \& Darusman, D. 2011. Pengaruh Umur Reklamasi Lahan bekas Tambang Batubara Terhadap Fungsi Hidrologis. Jurnal Hidrolitan, Volume 2, pp. 60-73.

Peraturan Menteri ESDM Nomor 7 Tahun 2014. Pelaksanaan Reklamasidan Pascatambang pada Kegiatan Usaha Pertambangan Mineral dan Batubara. Jakarta: Kemen ESDM.

Pongtuluran, Y. 2015. Manajemen Sumber Daya Alam \& Lingkungan. Yogyakarta: ANDI OFFSET. 
